\title{
Sexual satisfaction and associated individual factors among midlife and older people in Ile-Ife, Southwest Nigeria: implications for sexual and reproductive health
}

\author{
Rhoda Oluwatofunmi Omotosho, Bola Lukman Solanke*
}

Department of Demography and Social Statistics, Obafemi Awolowo University, Ile-Ife, Osun State, Nigeria

Received: 07 July 2020

Accepted: 05 September 2020

\section{*Correspondence:}

Dr. Bola Lukman Solanke,

E-mail: bsolanke@oauife.edu.ng

Copyright: (C) the author(s), publisher and licensee Medip Academy. This is an open-access article distributed under the terms of the Creative Commons Attribution Non-Commercial License, which permits unrestricted non-commercial use, distribution, and reproduction in any medium, provided the original work is properly cited.

\begin{abstract}
Background: Studies in Nigeria have rarely documented the prevalence and associated factors of sexual satisfaction among the midlife and older persons as a special group of underserved population in the country. This study investigates the prevalence and individual associated factors of sexual satisfaction among the midlife and older people in Ile-Ife, Southwest Nigeria.

Methods: A sample size of 404 was analysed in the study. The outcome variable was sexual satisfaction. The explanatory variables are sets of individual and relational characteristics. Data were analysed using Stata 14. Bivariable and multivariable binary logistic regression models were estimated.

Results: Findings reveal $42.0 \%$ level of sexual satisfaction. Higher educational attainment $(A O R=0.864, p<0.01 ; 95 \%$ CI: 0.841-0.886), longer length of marriage ( $\mathrm{AOR}=0.931, \mathrm{p}<0.01 ; 95 \% \mathrm{CI}: 0.912-0.950)$, remarriage $(\mathrm{AOR}=0.536$, $\mathrm{p}<0.01$; 95\% CI: 0.387-0.742), economic inactivity (AOR=0.456, $\mathrm{p}<0.01$; 95\% CI: $0.322-0.646$ ) reduces the odds of sexual satisfaction while absence of serious health challenges (AOR=2.742, p<0.01; 95\% CI: 1.594-4.716) and spousal high wealth level (AOR=1.038, p<0.01; 95\% CI: 1.017-1.059) increase the odds of sexual satisfaction.

Conclusions: Individual characteristics of midlife and older men and women are significantly associated with their sexual satisfaction. These characteristics should be targeted in a special programme focusing on midlife and older persons in Nigeria.
\end{abstract}

Keywords: Midlife, Nigeria, Older person, Sexual health, Sexual satisfaction

\section{INTRODUCTION}

Sexual satisfaction refers to individual subjective assessment of the level of satisfaction or happiness arising from their sexual relationship. ${ }^{1-2}$ Sexual satisfaction is a key measure of sexual health that is intricately linked to marital satisfaction and quality of life. ${ }^{3-9}$ Across the world, poor sexual satisfaction has been widely reported to cause depression and other mental challenges among all segments of men and women. ${ }^{10-14}$ However, the effects of sexual satisfaction among the midlife and older people deserves more research attention because the sexual health of these groups of men and women particularly older people are underserved in most sexual and reproductive health services. This may undermine the sexual and reproductive health and rights of older men and women. ${ }^{15}$ In Nigeria, the current National Reproductive Health Policy particularly notes that the health issues of older population groups are largely ignored in the reproductive health field. It also stressed that the increasing population of older persons in the country demands more attention to the health issues including sexual health issues of older persons. ${ }^{16}$

In Nigeria as well as other countries, numerous studies have specifically examined sexual activities and 
satisfaction among midlife men and women. ${ }^{17-22}$ Some other studies have solely focused older men and women. ${ }^{23-25}$ Fewer studies in other countries have also compared the prevalence and correlates of sexual satisfaction among the midlife and older persons. ${ }^{26-28}$ However, studies in Nigeria have rarely documented the prevalence and associated individual factors of sexual satisfaction among the midlife and older persons as a special group of underserved population in the country. This study intends to fill the knowledge gap by investigating the prevalence and individual associated factors of sexual satisfaction among the midlife and older people in Ile-Ife, Southwest Nigeria with the view to providing additional information about the sexual and reproductive health concerns of special segments of the Nigerian population. Ile-Ife, Southwest Nigeria was selected for the study because of the widely practiced sexual norm tagged the 'oluku' in the community. ${ }^{29}$ This practice did not frown at extra marital relationship or intergenerational sexual relationship and may impact the level of sexuality among midlife and older people in the community.

\section{METHODS}

\section{Study design and sample size}

The study adopted a quantitative cross-sectional design. The two Local Government Areas (LGAs) in Ile-Ife (Ife Central and Ife East LGA) were purposively selected for the study. The sample was selected through a multi-stage sampling process. In the first stage, the Headquarters of the selected LGAs (Ile-Ife and Oke Ogbo) were purposively selected for the survey for the ease of locating localities used as primary sampling units. A list of the localities was compiled and used as the sampling frame. Two localities were then selected randomly from the LGAs. In the selected localities, house listing were carried out and from the list, households were selected for the study using systematic random sampling method. In selected households, eligible men and women were identified. These were women and men aged 40-59 (midlife) and 60 or older (older persons). The sample was then selected among eligible men and women who gave verbal consent to participate in the study. The fieldwork was carried out between September-October, 2018. The sample size of 404 was determined for the study by applying the Cochran (1963) formula: $\mathrm{N}=\mathrm{Z}^{2} \mathrm{pq} / \mathrm{e}^{2}$, where $\mathrm{Z}=1.96, \mathrm{p}=0.37$ and $\mathrm{e}=0.05 .^{30}$

\section{Research instrument}

A structured questionnaire was designed for the study based on modifications to the sexual satisfaction scale adapted and validated in a recent study. ${ }^{8}$ The questionnaire sought information on the background characteristics, sexual activities, assessment of sexual satisfaction, and associated individual factors of sexual satisfaction. The instrument was pre-tested among childbearing women who are not part of the target population.

\section{Research variables}

The outcome variable was sexual satisfaction originally measured using the Likert scale. However, responses were later grouped into 'satisfied' coded ' 1 ' and 'not satisfied' coded ' 0 '. The explanatory variables are sets of background characteristics and relational factors such as gender (male or female), age group (midlife or older), education (none, primary, secondary or higher), religion (Christianity or Islam), marital status (currently married, separated or widowed), length of marriage (1-9 years, 1019 years or 20 years or more), remarriage (yes or no), have serious health challenges such as any noncommunicable disease (yes or no), recent sexual activity (active or inactive), spouse education (none, primary, secondary or higher), spouse wealth level (low, medium or high). These variables are selected based on significance in existing studies. ${ }^{31-33}$

\section{Data processing and analysis}

Data entry was processed using EPI data. The data were exported to Stata 14 for analysis. Respondents' characteristics were described using descriptive statistical methods. An unadjusted binary logistic regression model using Unadjusted Odds Ratio (UOR) with 95\% confidence interval was fitted to select variables into an adjusted model. The cutoff point was set at $\mathrm{p}<0.25$. An adjusted binary logistic regression model using Adjusted Odds Ratio (AOR) with 95\% confidence interval was estimated to assess the effects of the covariates on sexual satisfaction. Statistical significance was set at $\mathrm{p}<0.05$.

\section{RESULTS}

The distribution of participants by sex was nearly equal (50.5\% versus 49.5$)$. Similarly, the proportions of midlife and older people was similar (49.5\% versus $50.5 \%)$. Most of the respondents are educated but higher proportion of the respondents had tertiary education (40.6\%). The majority of the respondents $(72.8 \%)$ are Christians compared to the $26.2 \%$ who were Muslims. Currently married participants dominated the sample (91.6\%). More than half $(59.2 \%)$ of the respondents had been in a marital union between ten and nineteen years while slightly more than one third $(34.2 \%)$ of the respondents had been married for nine years or less. The majority $(86.1 \%)$ of the respondents have been in only one marital union. The majority $(96.5 \%)$ were economically active. Slightly more than half $(51.0 \%)$ did not have any serious health challenge but almost equal proportion (49.0\%) had at least one serious health challenge such as diabetes or high blood pressure.

The majority (78.2\%) of the respondents were sexually active. Spousal educational attainment had similar distribution with individual educational attainment. Most 
(49.0\% of the respondents' spouses were in the low wealth group compared to the proportion in high wealth group $(34.7 \%)$.

Table 1: Percentage distribution of respondents' socio-demographic characteristics.

\begin{tabular}{|c|c|c|}
\hline Characteristic & $\begin{array}{l}\text { Frequency } \\
(n=404)\end{array}$ & Percentage \\
\hline \multicolumn{3}{|l|}{ Gender } \\
\hline Male & 204 & 50.5 \\
\hline Female & 200 & 49.5 \\
\hline \multicolumn{3}{|l|}{ Age group } \\
\hline Midlife & 200 & 49.5 \\
\hline Older & 204 & 50.5 \\
\hline \multicolumn{3}{|l|}{ Education } \\
\hline None & 22 & 5.4 \\
\hline Primary & 58 & 14.4 \\
\hline Secondary & 160 & 39.6 \\
\hline Higher & 164 & 40.6 \\
\hline \multicolumn{3}{|l|}{ Religion } \\
\hline Christianity & 294 & 72.8 \\
\hline Islam & 110 & 26.2 \\
\hline \multicolumn{3}{|l|}{ Marital status } \\
\hline Currently married & 370 & 91.6 \\
\hline Separated & 8 & 2.0 \\
\hline Widowed & 26 & 6.4 \\
\hline \multicolumn{3}{|c|}{ Length of marriage } \\
\hline $1-9$ years & 138 & 34.2 \\
\hline $10-19$ years & 239 & 59.2 \\
\hline 20 years or more & 27 & 6.6 \\
\hline \multicolumn{3}{|l|}{ Remarriage } \\
\hline No & 348 & 86.1 \\
\hline Yes & 56 & 13.9 \\
\hline \multicolumn{3}{|c|}{ Economically active } \\
\hline Yes & 392 & 96.5 \\
\hline No & 12 & 3.5 \\
\hline \multicolumn{3}{|c|}{ Have serious health challenges } \\
\hline Yes & 198 & 49.0 \\
\hline No & 206 & 51.0 \\
\hline \multicolumn{3}{|c|}{ Recent sexual activity } \\
\hline Yes & 316 & 78.2 \\
\hline No & 88 & 21.8 \\
\hline \multicolumn{3}{|l|}{ Spouse education } \\
\hline None & 44 & 10.9 \\
\hline Primary & 64 & 15.8 \\
\hline Secondary & 138 & 34.2 \\
\hline Higher & 158 & 39.1 \\
\hline \multicolumn{3}{|c|}{ Spouse wealth level } \\
\hline Low & 198 & 49.0 \\
\hline Middle & 66 & 16.3 \\
\hline High & 140 & 34.7 \\
\hline \multicolumn{3}{|l|}{ Sexual satisfaction } \\
\hline No & 234 & 58.0 \\
\hline Yes & 170 & 42.0 \\
\hline
\end{tabular}

Source: Fieldwork.
Result further show that $42.0 \%$ of the respondents were satisfied with their sexual relationship compared to the $58.0 \%$ who were not satisfied (Table 1).

Sexual satisfaction was higher among males compared to females (52.9\% versus 31.0). Likewise, the midlife men and women had higher level of sexual satisfaction compared to older people (50.0\% versus $34.3 \%)$.

Respondents with primary education were more sexually satisfied than other respondents. Muslim respondents reported higher level of sexual satisfaction than Christians (44.5\% versus $41.2 \%$ ). Separated respondents had higher level of sexual satisfaction compared to the currently married and widowed respondents.

Higher level of sexual satisfaction was reported by respondents who had been in a marital union between 10 to nineteen years. Respondents who remarried had higher level of sexual satisfaction compared to those not remarked (46.4\% versus $41.4 \%)$.

Respondents who were economically active had higher level of sexual satisfaction while respondents who had no serious health challenges were also more sexually satisfied. Respondents whose partners were in the high wealth group reported higher level of sexual satisfaction (Table 2).

In the unadjusted binary logistic regression model fitted. Only marital status did not reveal a significant association with sexual satisfaction.

This variable was thus omitted in the adjusted model. In the adjusted model, females were $3.6 \%$ less likely to be sexually satisfied compared to males (AOR $=0.964$, $\mathrm{p}<0.01$; 95\% CI: 0.949-0.970). Older people were $8.2 \%$ less likely to be sexually satisfied compared to midlife men and women $(\mathrm{AOR}=0.918, \mathrm{p}<0.01 ; 95 \% \mathrm{CI}$ : 0.9070.928).

Respondents who attained higher education were $13.6 \%$ less likely to be sexually satisfied compared to the uneducated $(\mathrm{AOR}=0.864, \mathrm{p}<0.01 ; 95 \% \mathrm{CI}$ : 0.841-0.886). Muslims had higher odds of sexual satisfaction compared to Christians $(\mathrm{AOR}=1.121, \mathrm{p}<0.01 ; 95 \% \mathrm{CI}: 1.105-$ 1.136).

Long length of marriage $(\mathrm{AOR}=0.931, \mathrm{p}<0.01 ; 95 \% \mathrm{CI}$ : $0.912-0.950)$, remarriage $(\mathrm{AOR}=0.536, \mathrm{p}<0.01 ; 95 \% \mathrm{CI}$ : 0.387-0.742), being not economically active (AOR $=0.456, \mathrm{p}<0.01 ; 95 \% \mathrm{CI}: 0.322-0.646)$, and lack of recent sexual activity $(\mathrm{AOR}=0.471, \mathrm{p}<0.01 ; 95 \% \mathrm{CI}$ : 0.333-0.667) are all associated with lower odds of sexual satisfaction, while having serious health challenges $(\mathrm{AOR}=2.742, \mathrm{p}<0.01 ; 95 \% \mathrm{CI}:$ 1.594-4.716), higher spousal education $(\mathrm{AOR}=1.078, \mathrm{p}<0.01 ; 95 \% \mathrm{CI}$ : $1.066-$ $1.091)$ and high spousal wealth level (AOR $=1.038$, p<0.01; 95\% CI: 1.017-1.059) (Table 2). 
Table 2: Bivariable and multivariable results showing effects on sexual satisfaction.

\begin{tabular}{|c|c|c|c|c|c|c|c|c|}
\hline \multirow{2}{*}{$\begin{array}{l}\text { Characteristic predicting } \\
\text { sexual satisfaction }\end{array}$} & \multicolumn{2}{|c|}{ Sexual satisfaction } & \multicolumn{3}{|c|}{ Unadjusted model } & \multicolumn{3}{|c|}{ Adjusted model } \\
\hline & Yes (170) & No (234) & UOR & $\begin{array}{l}P \\
\text { value }\end{array}$ & $95 \% \mathrm{CI}$ & AOR & $P$ value & $95 \% \mathrm{CI}$ \\
\hline \multicolumn{9}{|l|}{ Gender } \\
\hline Male ${ }^{\text {ref }}$ & $\begin{array}{l}108 \\
(52.9)\end{array}$ & $\begin{array}{l}96 \\
(47.1)\end{array}$ & 1.000 & - & - & 1.000 & - & - \\
\hline Female & $62(31.0)$ & $\begin{array}{l}138 \\
(69.0)\end{array}$ & 0.932 & $\mathrm{p}<0.01$ & $\begin{array}{l}0.915- \\
0.949\end{array}$ & 0.964 & $\mathrm{p}<0.01$ & $\begin{array}{l}0.949- \\
0.979\end{array}$ \\
\hline \multicolumn{9}{|l|}{ Age group } \\
\hline Midlife $^{\text {ref }}$ & $\begin{array}{l}100 \\
(50.0)\end{array}$ & $\begin{array}{l}100 \\
(50.0)\end{array}$ & 1.000 & - & - & 1.000 & - & - \\
\hline Older & $70(34.3)$ & $\begin{array}{l}134 \\
(65.7)\end{array}$ & 0.977 & $\mathrm{p}<0.05$ & $\begin{array}{l}0.960- \\
0.993\end{array}$ & 0.918 & $\mathrm{p}<0.01$ & $\begin{array}{l}0.907- \\
0.928\end{array}$ \\
\hline \multicolumn{9}{|l|}{ Education } \\
\hline None ${ }^{\text {ref }}$ & $4(18.2)$ & $\begin{array}{l}18 \\
(81.8)\end{array}$ & 1.000 & - & - & 1.000 & - & - \\
\hline Primary & $30(51.7)$ & $\begin{array}{l}28 \\
(48.3)\end{array}$ & 0.994 & 0.430 & $\begin{array}{l}0.979- \\
1.009\end{array}$ & 1.008 & 0.222 & $\begin{array}{l}0.995- \\
1.022\end{array}$ \\
\hline Secondary & $62(38.8)$ & $\begin{array}{l}98 \\
(61.2)\end{array}$ & 0.979 & 0.016 & $\begin{array}{l}0.962- \\
0.996\end{array}$ & 0.984 & 0.070 & $\begin{array}{l}0.968- \\
1.001\end{array}$ \\
\hline Higher & $74(45.1)$ & $\begin{array}{l}90 \\
(54.9)\end{array}$ & 0.959 & $\mathrm{p}<0.01$ & $\begin{array}{l}0.940- \\
0.978\end{array}$ & 0.864 & $\mathrm{p}<0.01$ & $\begin{array}{l}0.841- \\
0.886\end{array}$ \\
\hline \multicolumn{9}{|l|}{ Religion } \\
\hline Christianity $^{\text {ref }}$ & $\begin{array}{l}121 \\
(41.2)\end{array}$ & $\begin{array}{l}173 \\
(58.8)\end{array}$ & 1.000 & - & - & 1.000 & - & - \\
\hline Islam & $49(44.5)$ & $\begin{array}{l}61 \\
(55.5)\end{array}$ & 0.921 & $\mathrm{p}<0.01$ & $\begin{array}{l}0.899- \\
0.943\end{array}$ & 1.121 & $\mathrm{p}<0.01$ & $\begin{array}{l}1.105- \\
1.136 \\
\end{array}$ \\
\hline \multicolumn{9}{|l|}{ Marital status } \\
\hline Currently married ${ }^{\text {ref }}$ & $\begin{array}{l}152 \\
(41.1)\end{array}$ & $\begin{array}{l}218 \\
(58.9)\end{array}$ & 1.000 & - & - & Omitted & & \\
\hline Separated & $6(75.0)$ & $2(25.0)$ & 0.992 & 0.792 & $\begin{array}{l}0.935- \\
1.052\end{array}$ & & & \\
\hline Widowed & $12(46.2)$ & $\begin{array}{l}14 \\
(53.8)\end{array}$ & 1.004 & 0.575 & $\begin{array}{l}0.989- \\
1.018 \\
\end{array}$ & & & \\
\hline \multicolumn{9}{|l|}{ Length of marriage } \\
\hline $1-9$ years $^{\text {ref }}$ & $56(40.6)$ & $\begin{array}{l}82 \\
(59.4)\end{array}$ & 1.000 & - & - & 1.000 & - & - \\
\hline $10-19$ years & $\begin{array}{l}104 \\
(43.5)\end{array}$ & $\begin{array}{l}135 \\
(56.5)\end{array}$ & 1.030 & $\mathrm{p}<0.01$ & $\begin{array}{l}1.018- \\
1.042\end{array}$ & 1.058 & 0.761 & $\begin{array}{l}0.737- \\
1.519\end{array}$ \\
\hline 20 years or more & $10(37.0)$ & $\begin{array}{l}17 \\
(63.0)\end{array}$ & 0.997 & 0.697 & $\begin{array}{l}0.983- \\
1.011\end{array}$ & 0.931 & $\mathrm{p}<0.01$ & $\begin{array}{l}0.912- \\
0.950\end{array}$ \\
\hline \multicolumn{9}{|l|}{ Remarriage } \\
\hline $\mathrm{No}^{\mathrm{ref}}$ & $\begin{array}{l}144 \\
(41.4)\end{array}$ & $\begin{array}{l}204 \\
(58.6)\end{array}$ & 1.000 & - & - & 1.000 & - & - \\
\hline Yes & $26(46.4)$ & $\begin{array}{l}30 \\
(53.6)\end{array}$ & 0.955 & $\mathrm{p}<0.01$ & $\begin{array}{l}0.943- \\
0.968\end{array}$ & 0.536 & $\mathrm{p}<0.01$ & $\begin{array}{l}0.387- \\
0.742\end{array}$ \\
\hline \multicolumn{9}{|l|}{ Economically active } \\
\hline Yes & $\begin{array}{l}168 \\
(42.9)\end{array}$ & $\begin{array}{l}224 \\
(57.1)\end{array}$ & 1.000 & - & - & 1.000 & - & - \\
\hline No & $2(16.7)$ & $\begin{array}{l}10 \\
(83.3)\end{array}$ & 0.964 & $\mathrm{p}<0.01$ & $\begin{array}{l}0.948- \\
0.981\end{array}$ & 0.456 & $\mathrm{p}<0.01$ & $\begin{array}{l}0.322- \\
0.646\end{array}$ \\
\hline \multicolumn{9}{|c|}{ Have serious health challenges } \\
\hline Yes & $12(6.1)$ & $\begin{array}{l}186 \\
(93.9)\end{array}$ & 1.000 & - & - & 1.000 & - & - \\
\hline No & $\begin{array}{l}158 \\
(76.7)\end{array}$ & $\begin{array}{l}48 \\
(23.3)\end{array}$ & 1.104 & $\mathrm{p}<0.01$ & $\begin{array}{l}1.092- \\
1.117\end{array}$ & 2.742 & $\mathrm{p}<0.01$ & $\begin{array}{l}1.594- \\
4.716\end{array}$ \\
\hline
\end{tabular}

Continued. 


\begin{tabular}{|c|c|c|c|c|c|c|c|c|}
\hline \multirow{2}{*}{$\begin{array}{l}\text { Characteristic predicting } \\
\text { sexual satisfaction }\end{array}$} & \multicolumn{2}{|c|}{ Sexual satisfaction } & \multicolumn{3}{|c|}{ Unadjusted model } & \multicolumn{3}{|c|}{ Adjusted model } \\
\hline & $\begin{array}{l}\text { Yes } \\
(170)\end{array}$ & $\begin{array}{l}\text { No } \\
(234)\end{array}$ & UOR & $\begin{array}{l}P \\
\text { value }\end{array}$ & $95 \% \mathrm{CI}$ & AOR & $P$ value & $95 \% \mathrm{CI}$ \\
\hline \multicolumn{9}{|l|}{ Recent sexual activity } \\
\hline Yes & $\begin{array}{l}140 \\
(44.3)\end{array}$ & $\begin{array}{l}176 \\
(55.7)\end{array}$ & 1.000 & - & - & 1.000 & - & - \\
\hline No & $30(34.1)$ & $\begin{array}{l}58 \\
(65.9)\end{array}$ & 1.115 & $\mathrm{p}<0.01$ & $\begin{array}{l}1.100- \\
1.131\end{array}$ & 0.471 & $\mathrm{p}<0.01$ & $\begin{array}{l}0.333- \\
0.667\end{array}$ \\
\hline \multicolumn{9}{|l|}{ Spouse education } \\
\hline None $e^{\text {ref }}$ & $8(18.2)$ & $\begin{array}{l}36 \\
(81.8)\end{array}$ & 1.000 & - & - & 1.000 & - & - \\
\hline Primary & $28(43.8)$ & $\begin{array}{l}36 \\
(56.2)\end{array}$ & 0.992 & 0.354 & $\begin{array}{l}0.976- \\
1.009\end{array}$ & 0.998 & 0.775 & $\begin{array}{l}0.987- \\
1.009\end{array}$ \\
\hline Secondary & $66(47.8)$ & $\begin{array}{l}72 \\
(52.2)\end{array}$ & 0.994 & 0.569 & $\begin{array}{l}0.973- \\
1.015\end{array}$ & 1.008 & 0.208 & $\begin{array}{l}0.995- \\
1.021\end{array}$ \\
\hline Higher & $68(43.0)$ & $\begin{array}{l}90 \\
(57.0)\end{array}$ & 0.944 & $\mathrm{p}<0.01$ & $\begin{array}{l}0.928- \\
0.961\end{array}$ & 1.078 & $\mathrm{p}<0.01$ & $\begin{array}{l}1.066- \\
1.091\end{array}$ \\
\hline \multicolumn{9}{|l|}{ Spouse wealth level } \\
\hline Low & $72(36.4)$ & $\begin{array}{l}126 \\
(63.6)\end{array}$ & 1.000 & - & - & 1.000 & - & - \\
\hline Middle & $28(42.4)$ & $\begin{array}{l}38 \\
(57.6)\end{array}$ & 0.993 & 0.342 & $\begin{array}{l}0.979- \\
1.007\end{array}$ & 1.040 & 0.136 & $\begin{array}{l}0.988- \\
1.095\end{array}$ \\
\hline High & $70(50.0)$ & $\begin{array}{l}70 \\
(50.0)\end{array}$ & 1.056 & $\mathrm{p}<0.01$ & $\begin{array}{l}1.044- \\
1.067\end{array}$ & 1.038 & $\mathrm{p}<0.01$ & $\begin{array}{l}1.017- \\
1.059\end{array}$ \\
\hline
\end{tabular}

Note: ref (reference category)

\section{DISCUSSION}

This study builds on existing studies that specifically examined sexual activities and satisfaction among midlife men and women and the studies that paid sole attention to older men and women. ${ }^{3,18-25}$ However, unlike few existing studies that compared the prevalence and correlates of sexual satisfaction among the midlife and older persons. ${ }^{26-28}$ This study investigated the prevalence and individual associated factors of sexual satisfaction among the midlife and older people as a distinct underserved segment of the Nigerian population.

The study found a $42.0 \%$ prevalence of sexual satisfaction in the study area. This prevalence was slightly lower than the $50.4 \%$ observed in a recent Ethiopian study. ${ }^{33}$ It is also lower than the $58.2 \%$ reported in an earlier study conducted in Iran..$^{32}$ The differences in the findings may however be due to the differences in the age range of people covered in the various samples. Regardless of the lower level of sexual satisfaction observed in the study, one important issue arising from the study is that midlife and older people in Ile-Ife, Nigeria and elsewhere are sexually active which provides support for earlier findings. ${ }^{18,20,22,33}$ Giving that midlife and older people are also sexually active, more attention should be giving to their sexual health in the country. Every person regardless of age or physical condition has equal right to sexual and reproductive health which must be preserved and protected by effective reproductive health services. Besides, research evidence abounds that poor sexual satisfaction among all categories of people may lead to serious mental health challenges which may further complicate the health conditions of older people. ${ }^{10-14}$

As already observed in a study and the 2017 National Reproductive Health Policy in Nigeria, the sexual health and rights of older people currently suffer from policy neglect across the world. ${ }^{15-16}$ This situation should be well-addressed by developing more initiatives to promote sexual health among midlife and older people. Such initiative should recognise that midlife and older adults are groups disproportionately affected by growing numbers of non-communicable diseases and reproductive system cancers such as breast, cervical and prostrate cancers. These health conditions should not be compounded by sexual problems that create depression and other psychological problems. One way of promoting the sexual health of midlife and older people is to develop a programme that specifically targets men and women experiencing andropause and menopause. This programme should create more awareness of likely physical and hormonal change as age increase and provide more information on how the change interacts with individual characteristics to affect sexual satisfaction.

\section{CONCLUSION}

This study investigated the prevalence and individual associated factors of sexual satisfaction among the midlife and older people in Ile-Ife, Southwest Nigeria. Findings in the study revealed substantial level of sexual satisfaction in the population. The factors that reduce the likelihood of sexual satisfaction are higher educational 
attainment, longer length of marriage, remarriage, and economic inactivity. On the other hand, absence of serious health challenges and spousal high wealth level enhance the odds of sexual satisfaction. These findings indicated need for a special sexual health promotional strategy that should target midlife and older persons in Nigeria.

\section{ACKNOWLEDGMENTS}

Authors would like to thank to all men and women who participated in the survey.

Funding: No funding sources

Conflict of interest: None declared

Ethical approval: The study was approved by the Institutional Ethics Committee

\section{REFERENCES}

1. Lawrence K, Byers ES. Sexual satisfaction in long term heterosexual relationships: The interpersonal exchange model of sexual satisfaction. Personal Relationships. 1995;2:267-85.

2. Sprecher S, Cate R. Sexual satisfaction and sexual expression as predictors of relationship satisfaction and stability. In: Harvey J, Wenzel, A, Sprecher S, eds. Handbook of sexuality in close relationships. Mahwah, NJ: Lawrence Erlbaum. 2004:235-56.

3. Ikechukwu II. Perception of Contributory Factors to Marital Sexual Satisfaction among Married Persons in Ebonyi State University, Abakaliki, Nigeria: Implications for Family Health. Community Med Health Educ. 2014;4:313.

4. Sánchez-Fuentes M, Santos-Iglesias, P, Sierra JC. A systematic review of sexual satisfaction. International J Clinic Health Psychol. 2014;14:67-75.

5. Flynn TJ, Gow AJ. Examining associations between sexual behaviours and quality of life in older adults. Age and Ageing. 2015;44:823-8.

6. Borji M, Molavi S, Rahimi Z. The Effect of Sexual Satisfaction on the Quality of Life on Patients with Cardiovascular Disease. International J Medic Res Health Sci. 2016;5(12):70-5.

7. Francis HM, Garcia JR, Meyerson BE, Chomistek AK, Abbruzzi E. They Shall Be One: Sexual Satisfaction Among Men and Women Married in the LDS Faith. J Sex Marital Therapy. 2019;45(1):60-72.

8. Lee JT, Hu YL, Meston CM, Lin HH, Tseng HM. The sexual satisfaction scale for women (SSS-W): adaptation and validation of a traditional Chinese version in Taiwan. J Sex Marital Therapy. 2019.

9. Bilal A, Rasool S. Marital satisfaction and satisfaction with life: mediating role of sexual satisfaction in married women. Journal of Psychosexual Health. 2020; 2(1):77-86.

10. Nik-Azin A, Nainian MR, Zamani M, Bavojdan MR, Bavojdan MR, Motlagh MJ. Evaluation of sexual function, quality of life, and mental and physical health in pregnant women. $\mathbf{J}$ of Family and Reprod Health. 2013;7(4):171-6.

11. Moghadam HM, Farhadi V, Feizi H. Relationship between sexual satisfaction, happiness and mental health among spouses District of Islamabad Gharb, in 2014-2013. J Appl Environ Biol Sci. 2014;4(8):202-7.

12. Mat Din H, Akahbar SAN, Ibrahim R. The association between depression and sexual satisfaction among Malay elderly in Malaysia. Heliyon. 2019;5:e01940.

13. Carcedo RJ, Perlman D, Fernandez-Rouco N, Perez F, Hervalejo D. Sexual Satisfaction and Mental Health in Prison Inmates. J Clin Med. 2019;8:705.

14. Carcedo RJ, Fernandez-Rouco N, Fernandez-Fuertes AA, Martinez-Alvarez JL. Association between Sexual Satisfaction and Depression and Anxiety in Adolescents and Young Adults. Int J Environ Res Public Health. 2020; 17: 841.

15. Aboderin I. Sexual and reproductive health and rights of older men and women: addressing a policy blind spot. Reproductive Health Matters. 2014;22(44):185-90.

16. Federal Ministry of Health. National Reproductive Health Policy 2017. Abuja, Nigeria: FMoH; 2017.

17. Tavakol Z, Nasrabadi AN, Moghadam ZB, Salehiniya H, Razaei E. A review of the factors associated with marital satisfaction. GMJ. 2017;6(3):197-207.

18. Bello FA, Daramola OO. Attitude to the menopause and sex amongst middle-aged women in a family medicine clinic in Ibadan, Nigeria. Obstetrics and Gynecol Int. 2016;2016.

19. Thomas HN, Hamm M, Borrero S, Hess R, Thurston RC. Body image, attractiveness, and sexual satisfaction among midlife women: a qualitative study. Journal Women's Health. 2018;28(1):100-6.

20. Harder H, Starkings RML, Fallowfield LJ, Menon U, Jacobs IJ, Jenkins VA, et al. Sexual functioning in 4,418 postmenopausal women participating in UKCTOCS: a qualitative free- text analysis. Menopause: The J The North Am Menopause Society. 2019;26(10):1100-9.

21. Agunbiade OM, Gilbert L. The night comes early for a woman: Menopause and sexual activities among urban older Yoruba men and women in Ibadan, Nigeria. J Women Aging. 2019;2019.

22. Egbewale BE, Adebimpe WO. Sexual behaviours among the elderly population in Osun State, Southwestern Nigeria. Elderly Health J. 2020;6(1):16-23.

23. Heywood W, Lyons A, Fileborn B, et al. Sexual satisfaction among older Australian heterosexual men and women: findings from the sex, age and Me study. J Sex Marital Ther. 2018;44(3):295-307.

24. Traeen B, Stulhofer A, Janssen E, Carvalheira AC, Hald GM, Lange T, et al. Sexual activity and sexual satisfaction among older adults in four european countries. Arch Sexual Behav. 2018;2018. 
25. Mat Din H, Raja Adnan RNE, Minhat HS. Association between sexual satisfaction and selfrated health among married older persons. Asia Proceedings Social Sci. 2019;4(1):10-2.

26. Heiman JR, Scott Long J, Smith SN, Fisher WA, Sand MS, Rosen RC. Sexual satisfaction and relationship happiness in midlife and older couples in five countries. Arch Sex Behav. 2011;40:741-53.

27. Thomas HN, Hess R, Thurston RC. Correlates of sexual activity and satisfaction in midlife and older women. Ann Fam Med. 2015;13:336-42.

28. Mernone L, Fiacco S Ehlert U. Psychobiological factors of sexual functioning in aging womenfindings from the women 40c healthy aging study. Front Psychol. 2019;10:546.

29. Agunbiade OM, Titilayo A. Ageing, sexuality and enhancement among Yoruba people in South western Nigeria. Culture, Health Sexuality. 2012;14(6):70517.

30. Asekun-Olarinmoye EO, Adebimpe WO, Bamidele JO, Odu OO, Asekun-Olarinmoye IO, Ojofeitimi EO. Barriers to use of modern contraceptives among women in an inner-city area of Osogbo metropolis, Osun State, Nigeria. Int J Women's Health. 2013;5:647-55.

31. Abdoly M, Pourmousavi L. The relationship between sexual satisfaction and education levels in women. Int J Women's Health Reproduction Sci. 2013;1(2):39-44.

32. Tavakol Z, Mirmolaei ST, Mansouri A, MomeniMovahed Z, Salehiniya H. Correlates of sexual satisfaction among Iranians women attending South Tehran health centers: a cross sectional study. J Anal Res Clin Med. 2014;2(3):135-41.

33. Zegeye B, Woldeamanuel GG, Negash W, Shibre G. Sexual satisfaction and its associated factors among married women in Kewot District, Northern Ethiopial. Ethiop J Health Sci. 2020;30(2):169.

Cite this article as: Omotosho RO, Solanke BL. Sexual satisfaction and associated individual factors among midlife and older people in Ile-Ife, Southwest Nigeria: implications for sexual and reproductive health. Int J Reprod Contracept Obstet Gynecol 2020;9:4045-51. 